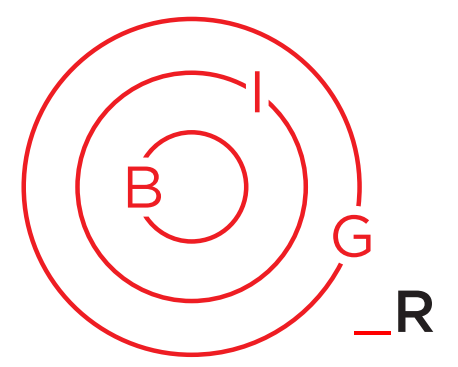

FILM REVIEW
Borders in Globalization Review

Volume 1, Issue 1 (Fall 2019): 135-136

https://doi.org/10.18357/bigr11201919274

\section{The Border on TV:}

What's so Fascinating about Crimes at the Border?

\section{Martin Klatt *}

\section{Border crime dramas on television}

The Danish-Swedish co-production Broen (The Bridge) has created a new format of crime shows on television in two ways. It is a fictional story of a single crime spread out to ten episodes of one hour, and it plays with the border phenomenon and crossborder police cooperation. Broen has so far had four seasons, first aired on Danish and Swedish TV from 2011 (season 1) to 2018 (season 4), translating into four crimes. The series' success has resulted in a direct US-Mexican and a UK-French remake and some "me-too" spin-offs as the Finnish Bordertown series or the German-Polish investigation team set in the real-life joint Polish-German police center on the border at Swiecko-Frankfurt (Oder) of the Polizeiruf 110 series.

The four seasons of Broen have four different, outrageous crimes as their main plot but are connected to each other by side plots evolving around the main characters, the respective Danish and Swedish primary investigators of the crime. All seasons start on or in view of the iconic Øresund Bridge connecting Denmark and Sweden since 2000, the symbol of the Øresund cross-border cooperation region. It also becomes clear from the beginning that the crime committed in each of the four seasons has a cross-border dimension. Furthermore, the series is close to actual political developments in Denmark and Sweden, and it plays with the linguistic and cultural differences between the two Scandinavian countries. These are also reflected in the personalities of the chief investigators especially in seasons 1-2. Saga Norén (played by Sofie Helin) is a super-intelligent detective, but autistic, whereas

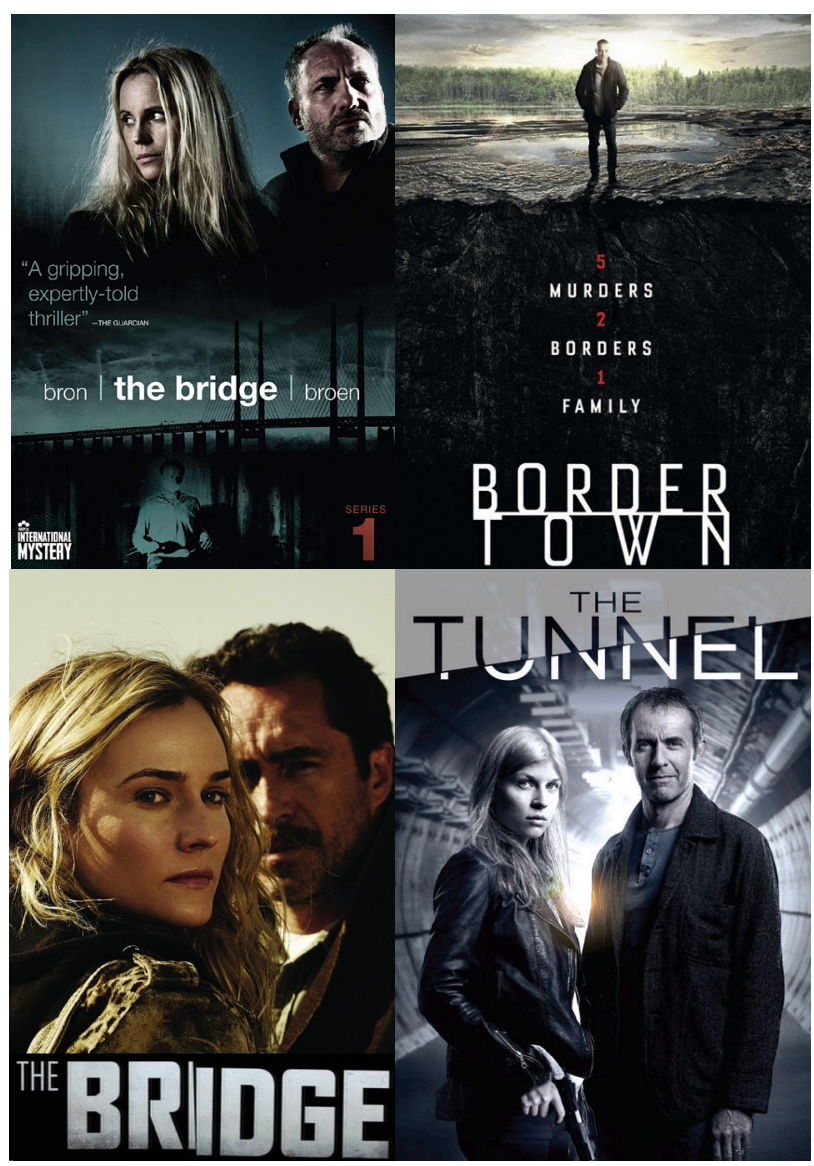

her Danish partner in season 1-2, Martin Rohde, has a more untraditional approach to policework. He is played by Kim Bodnia, who usually plays the violent crook with a soft heart under the shell, for example in I Kina spiser de hunde (In China, they eat dogs). Rohde kills the murderer of season 2 and goes to prison. He is replaced by the more sensitive Henrik Sabroe (played by Thure Lindhardt), who is trauma-

\footnotetext{
* Martin Klatt holds a PhD in History and is Associate Professor of Contemporary History at the Centre of Border Region Studies, Dept. of Political Science, at the University of Southern Denmark.
} 
Borders in Globalization Review | Volume 1 | Issue 1 | Fall 2019

Klatt, "The Border on TV: What's so Fascinating about Crimes at the Border?" (film review)

tized by the mysterious disappearance of his wife and their two daughters some years ago. In season four, Sabroe engages in a love affair with Saga Norén, entailing a lot of funny, ironic complications. The end is happy, but not kitch: Sabroe is united with his surviving daughter. Still it is not that he, Saga and his daughter live together forever happily after. Saga frees herself from her guilt complex and quits the police force to start a new life.

The US remake The Bridge, screened in El Paso and Juárez, follows the Danish-Swedish plot closely in season 1, whereas plots in seasons 1 and 2 also include US-Mexican issues such as disappeared and murdered female laborers in the maquiladora industries. In the UK-French remake The Tunnel, episode 1 is a direct copy of episode 1 of the Danish-Swedish production, but then the story develops more independently. The Finnish Bordertown operates with shorter plots: the different crimes only cover 2-3 episodes. There is more focus on the development of the side plot of the Finnish detective Kari Sorjonen (played by Ville Virtanen) who transfers to the border town of Lappeenranta from Helsinki and his family. Here, his wife's past as teenage girlfriend of the corrupt mayor and local tycoon sets a counterpoint to the eccentric detective and his methods. The cross-border element is his Russianspeaking colleague Lena Jaakola (Anu Sinisalo), who has a past in Russia's secret police FSB and continues to use their methods. The German-Polish Polizeiruf 110 is a German production but set in a German-Polish context in the real-life joint GermanPolish police commissariat in Swiecko, located in the modern joint border control facilities on the Berlin-Warszawa highway, which became obsolete when Poland joined the Schengen area in 2007. The two main investigators Olga Lenski (a German-Russian, played by Maria Simon) and Adam Raczek (a Pole having lived in Germany for many years, played by Lucas Gregorowicz) solve cases of crossborder relevance relating to German-Polish clichés and stereotypes. The latest was about rich German landowners expropriated after 1945 attempting to regain their lands with all means. The episodes demonstrate the sensitivity of German-Polish relations: war reparations unsettled, property issues, but also the East-West differences in lifestyle and prosperity.

While Broen's and The Bridge's plot about crossborder police cooperation is pure fiction, far from the reality of continuing separation of national and municipal police forces, the German Polizeiruf stories build on the real-life German-Polish Police Centre in operation since 2007. Police cooperation within the EU is a central part of the Schengen system of open borders, which allows police officers to cross borders in action of immediate pursuit and facilitates data exchange. It also includes the instrument of the European arrest warrant obliging any EU police force to arrest people searched in any EU member state. Still, institutionalized police cooperation does not exist across all EU member state borders.

Streaming: Broen and Bordertown can be streamed on Netflix. The French-UK remake is available on PBS in the US, the US-Mexican on Amazon Prime. Recent episodes of Polizeiruf 110 can be streamed worldwide from the German network ARD 